\title{
NEW SPECIES OF BOTHRIOCERA BURM. (HOMOPTERA: CIXIIDÆ) FROM THE LESSER ANTILLES
}

\author{
By R. G. FenNah \\ Entomologist, Citrus Pests Investigation, Windward and \\ Leeward Islands
}

In the present paper seven new species of Bothriocera Burm. are described. Five of them, B. cyanea, B. phantasma, B. riparia, B. daedala and $B$. hastata (see below), are apparently endemic in the one island from which each has been recorded: another species, $B$. longistyla, has been found only in two adjoining islands, while the seventh, B. eborea, has, by contrast, been taken in all islands where the writer has searched.

The relation of these species to Greater Antillean or mainland forms, and even to each other, is obscure, chiefly on account of the difficulty of assessing the value of the available morphological or chroic characters. As regards the pattern of the tegmina it is evident, from a scrutiny of over 700 specimens, that within any one island the pattern of a single species is constant, even in minute details; between islands, however, the differences in tegminal pigmentation of a single species are quite distinct, being revealed, not in changes of pattern, but in boldness of marking. In the genitalia the shape of the male genital styles seems to be a useful character, but forms which are allied in the possession of a common type show very different tegminal markings. On the whole, the writer is inclined to regard the following group of characters as providing the best basis for judging the affinity of Lesser Antillean species: (i) truncate styles of the $B$. hastata type, (ii) a periandrium with a process on the left side, (iii) a triangular median ventral process on the pygofer and (iv) an anal segment with the apical margin rounded. On the basis of possessing at least three of these characters all the species discussed below are allied with 
the exception of $B$. cyanea, a species which also stands apart by reason of its tegminal markings. For the rest it appears that the various genital and chroic characters are combined at random.

The holotype males and allotype females of all the species described have been deposited in the U. S. National Museum, while paratype series of both sexes have been sent to the British Museum (Natural History), the American Museum of Natural History, and the Museum of Comparative Zoology, Cambridge, Mass., U. S. A.

\section{Bothriocera Burmeister}

1835 Burmeister, Handbuch der Entomologie, p. 156. Haplotype B. tinealis Burm.

\section{Bothriocera cyanea sp. $n$.}

Male. Length, $3.5 \mathrm{~mm}$; tegmen, $3.9 \mathrm{~mm}$. Female. Length, 3.8 $\mathrm{mm}$; t tegmen, $4.2 \mathrm{~mm}$. Frons and clypeus piceous, lateral margins pale, almost white; genae piceous, antennal pit white; vertex piceous. Pronotum piceous, but almost white laterad on posterior half. Mesonotum dark, thorax fuscous ventrally. Fore legs piceous, middle and hind legs pale testaceous. Abdomen and genitalia brown. Tegmina pale yellow basally, smoky brown beyond a line from stigma to apex of clavus, clavus dark; stigma dark, often traversed by two parallel crimson lines. Wings smoky, pale at base. Insect in life densely powdered purplish blue and sulphur yellow.

Anal segment of male truncate at apex, lateral angles pointed. Periandrium tubular, penis forming a complete loop round periandrium, outer border minutely serrate distally. Genital styles with apex broadly rounded, a thin lobe lateroventrally at right angles. A small knob at outer angle. Inner border of style concave at base, convex distally. Median ventral process of pygofer semicircular with a minute point at apex.

Described from 17 males and 14 females collected by the writer at $800 \mathrm{ft}$. in mountain forest near the Imperial Road, Dominica, B. W. I. (June 11-30, 1939; June 15-29, 1940) resting on Palicourea crocea and Inga laurina. This species is distinguished by the male genitalia and by the dark tegmina with a pale basal spot. 
Bothriocera phantasma sp. $\mathrm{n}$.

Male. Length, $2.9 \mathrm{~mm}$; tegmen, $3.5 \mathrm{~mm}$. Female. Length, 3.0 $\mathrm{mm}$; ; tegmen, $3.8 \mathrm{~mm}$. Frons, clypeus, genae, vertex and pronotum white or pale yellow. Mesonotum piceous, pleura pale; coxae smoky, profemora smoky, pro-tibiae and tarsi, middle and hind legs very pale. Abdominal sternites and membrane pale, tergites and genitalia fuscous. Tegmina transparent; a spot at apex of costal cell, a dark line from stigma to apex of clavus sharply interrupted in middle, crossveins of apical region dark; two spots on $\mathrm{R}$ veins near apex of costal margin; a dark spot at base of $\mathrm{Cu}$; clavus smoky posterior to veins. Wings transparent, smoky towards base of anal veins. Insect in life powdered greyish.

Anal segment of male truncate apically, apical angles produced into large rounded lobes. Periandrium tubular, a broad hook-like process directed dorsally and anteriorly on left side near apex. Penis broadest in middle, forming loop of 270 degrees, minutely serrate at apex and at base near junction with apodeme. Genital style with inner margin concave at base, convex in middle, slightly concave at apex, posterior angle only just obtuse; apex truncate; inner angle slightly produced. Median process on pygofer between base of styles forming an isosceles triangle with angles truncate.

Described from 15 males and 12 females collected by the writer at $1,000 \mathrm{ft}$. in mountain forest near the Imperial Road, Dominica, B. W. I. (June 15-29, 1940) on epiphytic aroids.

Bothriocera riparia sp. $\mathrm{n}$.

Male. Length, $4.6 \mathrm{~mm}$; tegmen, $5.0 \mathrm{~mm}$. Female. Length, 4.7 $\mathrm{mm}$.; tegmen, $5.1 \mathrm{~mm}$. Head, thorax, legs, abdomen and genitalia (excluding ovipositor) white; abdominal tergites occasionally fuscous, abdomen sometimes tinged with pink; ovipositor fuscous. Tegmina transparent, slightly yellow; stigma black, a dark spot contiguous posteriorly; a dark spot at first fork of $\mathrm{M}$; subapical cross-veins pale smoky; a dark trace at base of second apical cell of $\mathrm{R}$; clavus pale. Wings transparent. Insect in life powdered grey.

Anal segment of male bluntly rounded at apex; periandrium tubular with an elongated vertical process, rounded at apex, on left side; penis wide apically, a large evenly-serrated lobe attached to middle, inner margin serrate, membrane minutely denticulate near apex. Inner border of genital styles with two indentations, obtusely 
angled at apex; apex truncate. Median ventral process of pygofer forming an isosceles triangle with sides convex in apical half.

Described from 27 males and 33 females collected by the writer at 2,000 ft. on Morne Garu (Aug. 20, 21, 1941), and at Three Rivers (Sept. 3-5, 1941), St. Vincent, B. W. I., mostly resting on Tabernaemontana sp. and Heliconia bihai. The species is distinguished by the pattern of the tegmina, which, though of a common type, is characteristic in its details, and by the conspicuous processes on the periandrium and penis.

\section{Bothriocera longistyla sp. $\mathrm{n}$.}

Male. Length, $3.4 \mathrm{~mm}$; tegmen, $4.2 \mathrm{~mm}$. Female. Length, 3.5 $\mathrm{mm}$.; tegmen, $4.4 \mathrm{~mm}$. Frons, clypeus, vertex, pronotum and legs pale testaceous, margins of antennal pit narrowly fuscous; mesonotum dark testaceous or fuscous; abdomen and genitalia brown or fuscous. Tegmina transparent, ivory yellow; veins lightly clouded, except $\mathrm{R}, \mathrm{M}$, and $\mathrm{Cu}$ at base; an interrupted narrow band from stigma to apex of clavus; subapical cross-veins narrowly clouded; clavus pale, smoky behind posterior vein. Wings transparent, clouded over part of anal area. Insect in life powdered grey.

Anal segment of male with posterior border bluntly rounded. Periandrium tubular, a broad process on left side tapering to a point anteriorly. Penis looping in a semicircle, irregularly serrate along margin, tapering to a fine point. Genital styles narrow, elongate, obtusely angled near middle, tapering slightly to a blunt point at tip. Median ventral process of pygofer subconically rounded.

Described from 30 males and 41 females collected by the writer at $1,000 \mathrm{ft}$. in mountain forest near Quilesse, St. Lucia, B. W. I. (March 20, 21, 1939) and on Morne Fortunée, St. Lucia at $750 \mathrm{ft}$. (Feb. 2-5, 1940), resting on Miconia sp., Tabernaemontana sp., and Inga laurina. The species is readily distinguished by its pale tegmina and long tapering styles, and by the shape of the periandrium. A long series from Morne Garu, St. Vincent, B. W. I. (coll. R. G. F. Aug. 20, 21, 1941) is assigned to this species, but differs constantly in having the tegmina wholly transparent and unmarked, and a periandrial process with a broader base. The St. Lucian variety is designated as B. longistyla var. vulgaris and the St. Vincent variety as B. longistyla var. pallida. 
Bothriocera daedala sp. $\mathrm{n}$.

Male. Length, $3.0 \mathrm{~mm}$; tegmen, $3.4 \mathrm{~mm}$. Female. Length, 3.1 $\mathrm{mm}$; t tegmen, $3.7 \mathrm{~mm}$. Frons and clypeus pale yellow, lateral margins slightly darker, vertex and margin of antennal pit piceous; genae and antennae pale yellow. Pronotum pale or dark, pale laterally; mesonotum fuscous. Ventral surface of thorax pale, legs slightly darker; abdominal tergites and sternites fuscous, genitalia fuscous. Tegmina pale basally, mostly dark distad of a line from stigma to apex of clavus, a pale spot just distad of stigma, a small spot distad of this on margin; a round pale spot posterior to stigma in middle of tegmen; apical cells almost entirely pale to apical margin; a small dark spot between M1a and M1b; apical cells of $\mathrm{Cu}$ and clavus wholly dark. Wings smoky, pale basally, a pale spot apically. Insect in life powdered blue-grey.

Anal segment of male truncate apically in a straight line. Periandrium tubular, with a large broad lobe on left side near apex directed dorso-anteriorly to a blunt point. Penis looping for slightly more than a semicircle, a small lobe with about eight teeth on dorsal side in middle; an irregular line of teeth from inner side near base of penis to dorsal margin one third from apex. Genital styles with inner border concave at base, obtusely angled apically; apex truncate. Median process of pygofer between styles in form of an isosceles triangle with convex sides, apex pointed.

Described from 64 males and 71 females collected by the writer at $1,000 \mathrm{ft}$. in mountain forest near the Imperial Road, Dominica, B. W. I. (June 11-30, 1939; June 15-29, 1940) resting on low bushes. This species is distinguished by the pattern of the tegmina, which is somewhat similar to that of $B$. signoreti Stål, and by the male genitalia.

\section{Bothriocera hastata sp. $\mathrm{n}$.}

Male. Length, $3.2 \mathrm{~mm}$; tegmen, $3.6 \mathrm{~mm}$. Female. Length, 3.6 $\mathrm{mm}$.; tegmen, $4.0 \mathrm{~mm}$. Frons piceous, testaceous laterally; clypeus fuscous, narrowly pale laterally; antennae pale. Vertex, pro- and mesonotum piceous. Femora smoky, protibiae and tarsi smoky, mesotibiae and tarsi testaceous, metatibiae and tarsi very pale. Abdomen and genitalia fuscous. Tegmina pale yellow basally; a fuscous spot at apex of costal cell, a broad dark band from stigma to apex of clavus, tegmina distad of this line mostly fuscous; a transparent spot 
distad of stigma, a large round transparent spot posterior to this, a small pale spot at margin between $\mathrm{Sc}$ and $\mathrm{R}$, a minute spot between M1 and M2, an elongated pale spot subapically crossing four apical cells. Wings smoky, pale basally, a pale round spot in apical half. Insect in life powdered bluish-grey.

Anal segment of male bluntly rounded at apex. Periandrium tubular, a long, somewhat narrow curved process on left side directed upward and anteriorly, beset with numerous minute teeth at tip. Penis somewhat narrow, looping in a semicircle; a bluntly conical projection near base, a few coarse teeth on inner border at basal quarter, a small but prominent coarsely-serrated crest just beyond middle. Genital styles with inner border concave basally, obtusely angled distally; apex truncate. Median ventral process of pygofer forming an isosceles triangle with sides slightly convex.

Described from 22 males and 24 females collected by the writer at 2,000 ft. in mountain forest on Morne Garu, St. Vincent, B. W. I. (Aug. 20 and 21, 1941), resting on Heliconia bihai and aroids. This species broadly resembles $B$. daedala but is well distinguished by the tegminal pattern, as well as by characters of the anal segment, the periandrium, and the penis. According to Mr. China this species is identical with specimens from St. Vincent identified by Uhler as B. signoreti Stål. It seems to be endemic in St. Vincent.

\section{Bothriocera eborea sp. $n$.}

Male. Length, $3.4 \mathrm{~mm}$.; tegmen, $4.1 \mathrm{~mm}$. Female. Length, 4.1 $\mathrm{mm}$.; tegmen, $4.8 \mathrm{~mm}$. Frons fuscous, testaceous towards and on lateral margins, clypeus pale medially, fuscous on each side of middle line, testaceous at margins, genae and antennal pits testaceous yellow; vertex pale fuscous, testaceous laterally. Pronotum testaceous; mesonotum, abdomen and genitalia piceous; legs dark testaceous. Tegmina with a dark band from stigma to apex of clavus; apical portion of veins, cross-veins, and membrane at apical margin clouded with brown; clavus wholly brown. Wings transparent basally, crossveins dark, distal portion of wings smoky. Insect in life powdered bluish-grey.

Anal segment of male rounded into a semicircle at apex. Periandrium tubular, dorsal border sinuate, terminating in a broad lobe directed anteriorly, slightly crenulate at rounded tip. Penis with a small curved coarsely-toothed process at base, a curved spine, often 
somewhat transparent, on inner margin one-third from base; at apex of membrane a very small projection at outer edge, and a long spinose recurved process at inner edge; a long curved transparent process arising two-thirds along penis and projecting anteriorly, terminating in a rounded, spatulate, or cup-like apex. Genital styles with inner border deeply concave at base, obtusely angled distally; outer border concave, apex truncate. Median ventral process of pygofer small, triangular.

Described from 14 males and 21 females collected by the writer at 1,300 ft. in forest near Ottley's Level, St. Kitts, B. W. I. (Jan. 26, 27, 1942) resting on Tabernaemontana sp. and on aroids.

The writer has long series of this species from other islands, collected as follows: 1,000 ft. in forest near Quilesse, St. Lucia, B. W. I. (coll. R. G. F. Mar. 20, 21, 1939); $800 \mathrm{ft}$. in forest near Mahaut, Dominica, B. W. I. (coll. R. G. F. June 14, 1939); $1,300 \mathrm{ft}$. in forest, Chance's Mountain, Montserrat, B. W. I. (coll. R. G. F. Jan. 18, 1939) ; 2,000 ft. in forest, Morne Garu, St. Vincent, B. W. I. (coll. R. G. F. Aug. 20, 21, 1941); 1,000 ft. in forest, Nevis, B. W. I. (coll. R. G. F. Jan. 18, 1942). There are differences in intensity of pigmentation between series from different islands, and the genitalia afford the only reliable means of identification.

\section{Explanation of Plate II}

\section{1-5 Bothriocera cyanea}

1. Anal segment of male, dorsal view; 2. Periandrium, lateral view; 3 . Penis, lateral view; 4. Genital style, lateral view; 5 . Median ventral process of pygofer.

\section{6-10 B. phantasma}

6. Anal segment of male, dorsal view; 7. periandrium, lateral view; 8. Penis, lateral view; 9. Genital style, lateral view; 10. Median ventral process of pygofer.

\section{1-15 B. riparia}

11. Anal segment of male, dorsal view; 12. Periandrium, lateral view; 13. Penis, lateral view; 14. Genital style, lateral view; 15. Median ventral process of pygofer.

16-20 B. longistyla

16. Anal segment of male, dorsal view; 17. Periandrium, lateral view; 18. Penis, lateral view; 19. Genital style, lateral view; 20. Median ventral process of pygofer.

21-25 B. daedala

21. Anal segment of male, dorsal view; 22. Periandrium, lateral view; 23. Penis, lateral view; 24. Genital style, lateral view; 25. Median ventral process of pygofer. 
26. Anal segment of male, dorsal view; 27 . Periandrium, lateral view; 28. Penis, lateral view ; 29. Genital style, lateral view ; 30. Median ventral process of pygofer.

$$
\text { 31-35 B. eborea }
$$

31. Anal segment of male, dorsal view; 32. Periandrium, lateral view; 33. Penis, lateral view; 34 . Genital style, lateral view; 35 . Median ventral process of pygofer. 36. B. phantasma, tegmen; 37. B. cyanea, tegmen; 38. B. hastata, tegmen; 39. B. daedala, tegmen; 40. B. eborea (St. Kitts), tegmen. 
Psyche, 1943

Vol. 50, Plate II
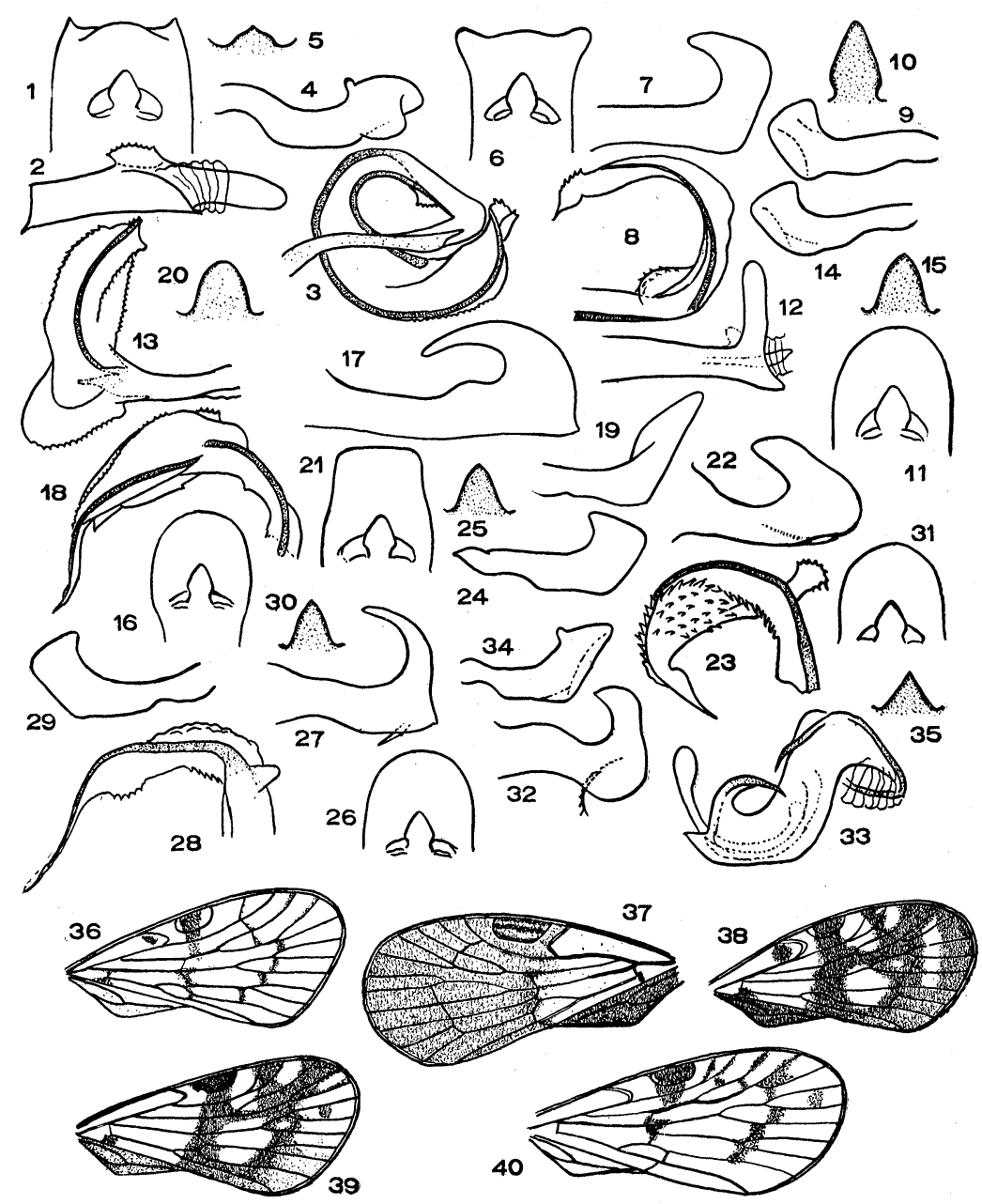

Fennah - New species of Bothriocera 

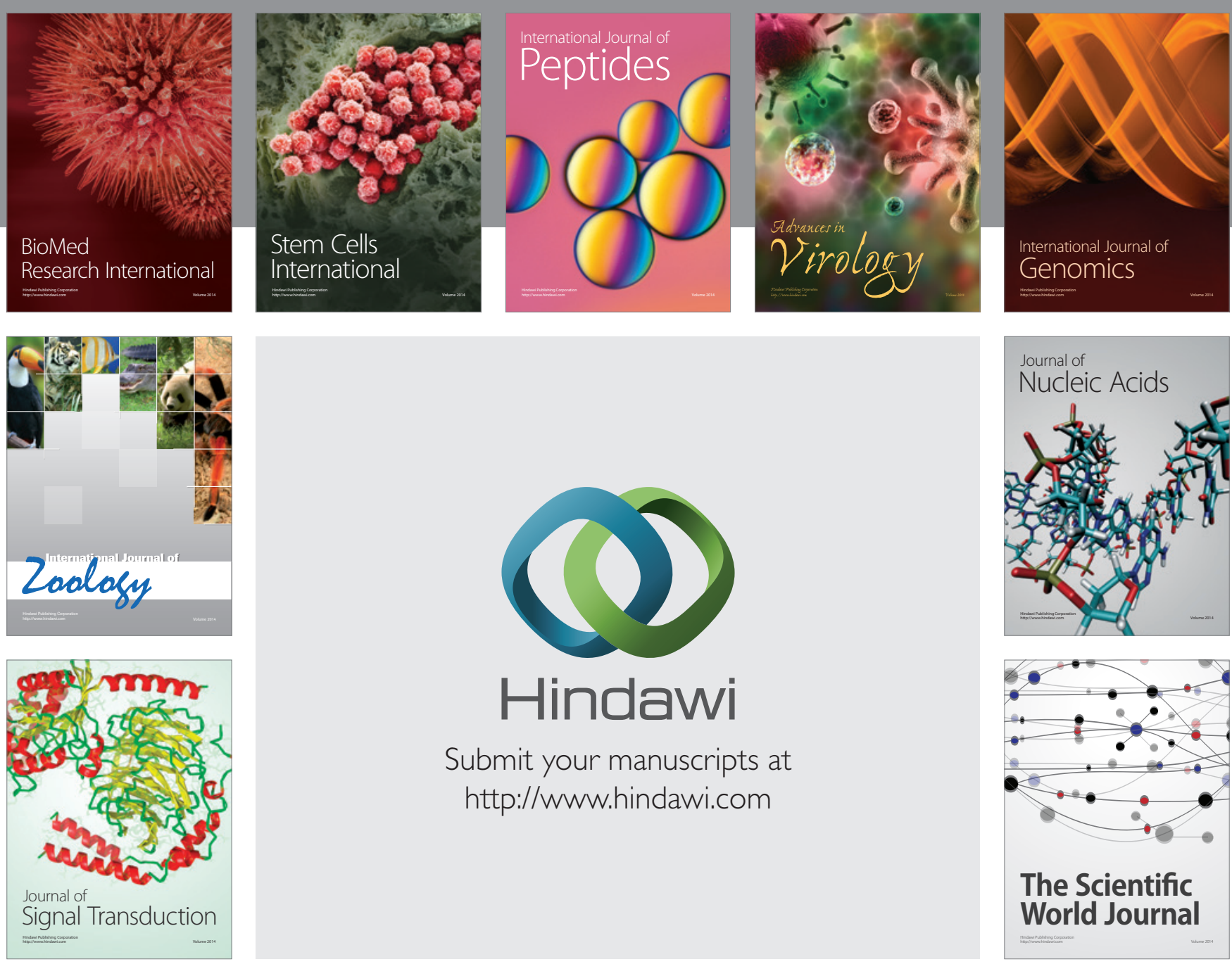

Submit your manuscripts at

http://www.hindawi.com
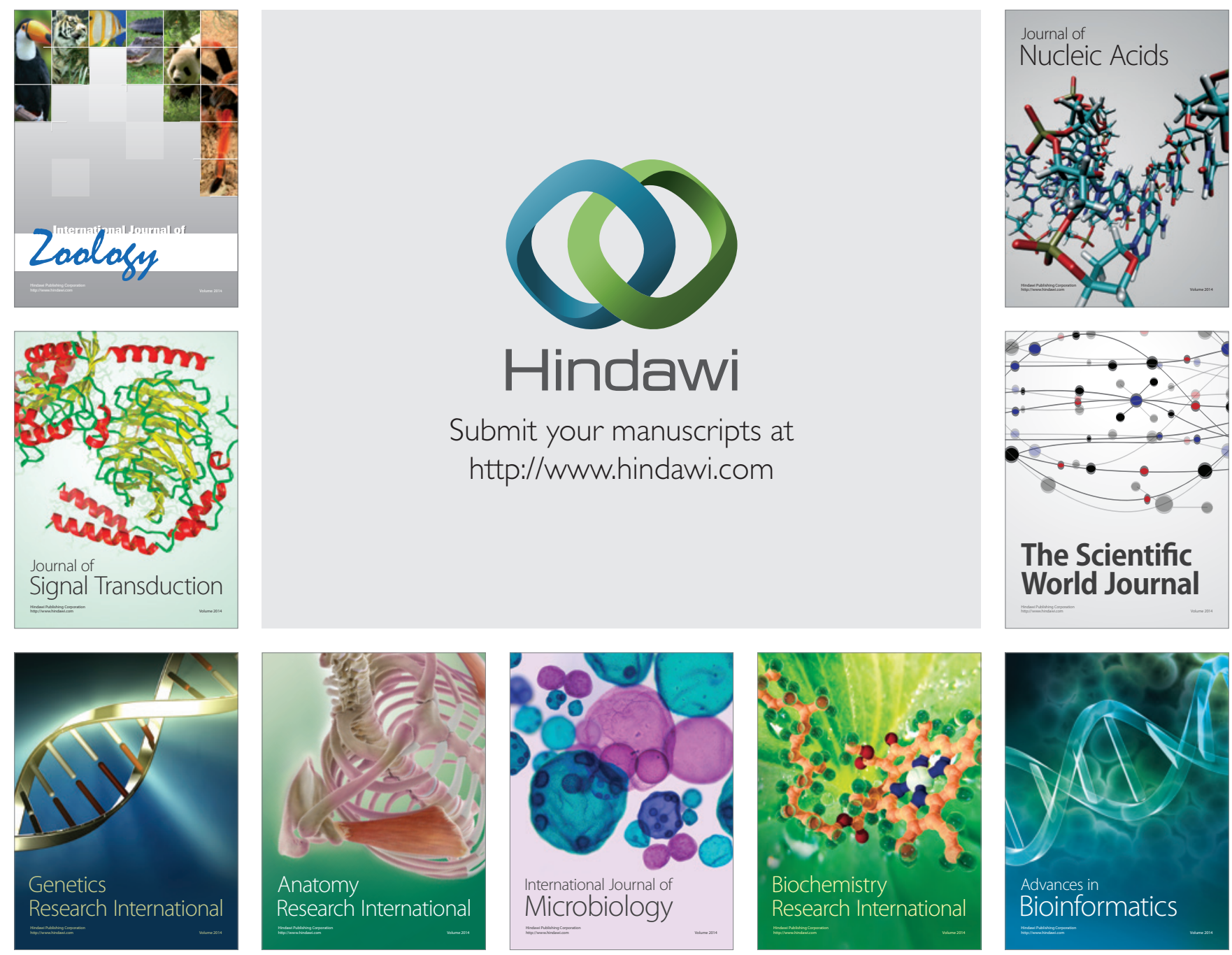

The Scientific World Journal
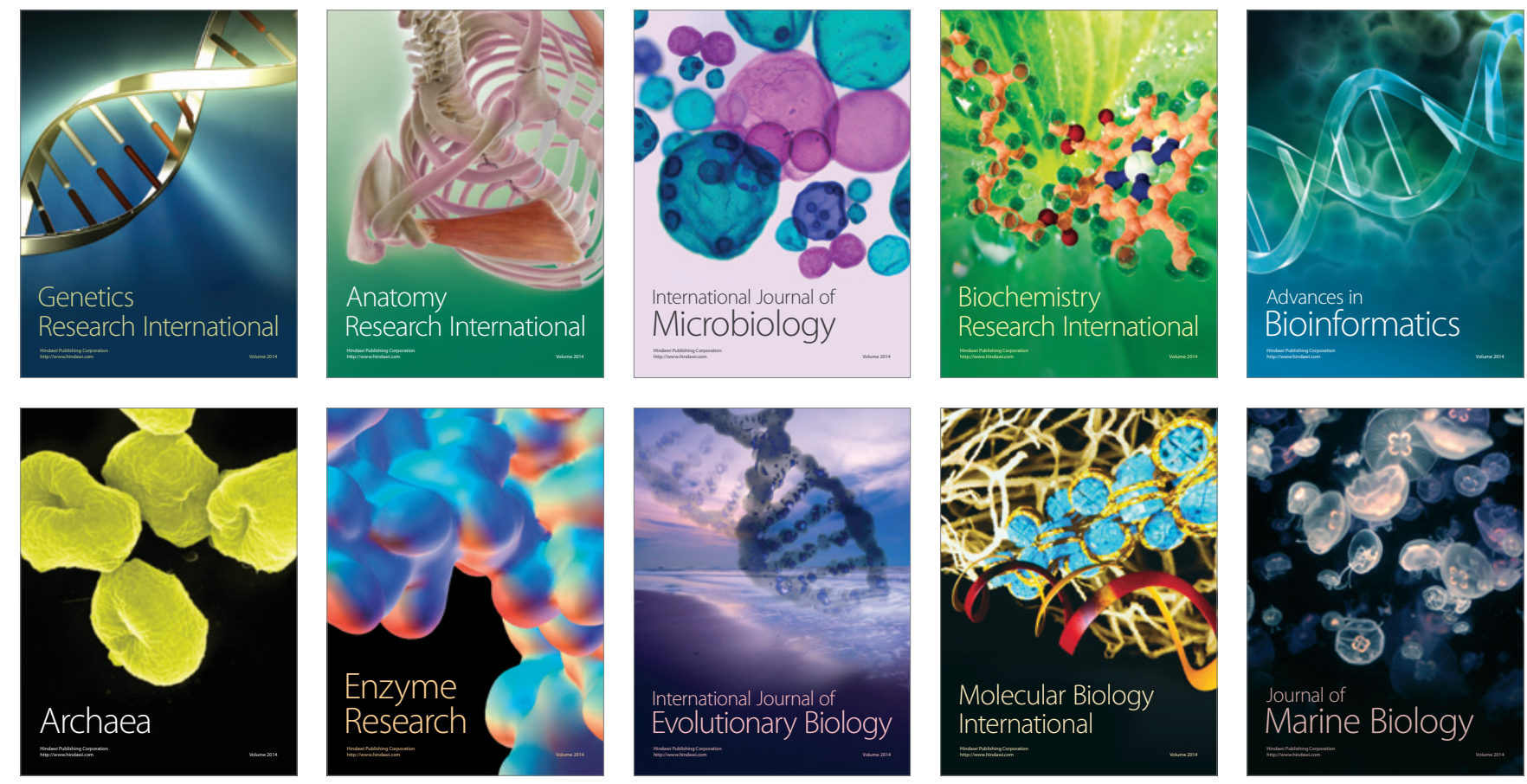